\title{
Toward a mechanistic understanding of how natural bacterial communities respond to changes in temperature in aquatic ecosystems
}

\author{
Edward K Hall ${ }^{1}$, Claudia Neuhauser and James B Cotner \\ Department of Ecology, Evolution and Behavior, University of Minnesota, St Paul, MN, USA
}

\begin{abstract}
We examine how heterotrophic bacterioplankton communities respond to temperature by mathematically defining two thermally adapted species and showing how changes in environmental temperature affect competitive outcome in a two-resource environment. We did this by adding temperature dependence to both the respiration and uptake terms of a two species, two-resource model rooted in Droop kinetics. We used published literature values and results of our own work with experimental microcosms to parameterize the model and to quantitatively and qualitatively define relationships between temperature and bacterioplankton physiology. Using a graphical resource competition framework, we show how physiological adaptation to temperature can allow organisms to be more, or less, competitive for limiting resources across a thermal gradient $\left(2-34{ }^{\circ} \mathrm{C}\right)$. Our results suggest that the effect of temperature on bacterial community composition, and therefore bacterially mediated biogeochemical processes, depends on the available resource pool in a given system. In addition, our results suggest that the often unclear relationship between temperature and bacterial metabolism, as reported in the literature, can be understood by allowing for changes in the relative contribution of thermally adapted populations to community metabolism. The ISME Journal (2008) 2, 471-481; doi:10.1038/ismej.2008.9; published online 7 February 2008
\end{abstract}

Subject Category: microbial population and community ecology

Keywords: resource competition; temperature-resource interactions; community succession; Droop model; variable yield model; bacterioplankton

\section{Introduction}

Heterotrophic prokaryotes (bacteria) play an essential role in every ecosystem on the planet. In oligotrophic aquatic systems, bacterioplankton often dominate the biota both in biomass and in metabolism (Azam et al., 1983; Cho and Azam, 1988). However, although the effect of temperature on individual taxa is well studied, the effect of temperature on the metabolism of natural bacterial communities remains unclear (Rivkin et al., 1996; del Giorgio and Cole, 2000). For example, in a survey of published literature, Rivkin et al. (1996) found only a weak positive correlation between temperature and specific growth rate with approximately two orders of magnitude variation around the trend, making it difficult to project how rising

Correspondence: EK Hall, Department of Freshwater Ecology, University of Vienna, Althanstr. 14, A-1090 Vienna, Austria.

E-mail: hall0506@umn.edu

${ }^{1}$ Current address: Department of Freshwater Ecology, University of Vienna, Vienna, Austria

Received 26 November 2007; accepted 17 December 2007; published online 7 February 2008 temperatures will affect extant bacterial communities. Such ambiguity most likely results from a variety of environmental and biological interactions with two key sources often being identified: (a) the interactive effects of temperature and resources on bacterial physiology and (b) changes in community composition of the bacterial community across temporal and spatial thermal gradients. While the interactive effects of nutrients on the metabolic response of bacteria to temperature have been thoroughly discussed in the literature (Pomeroy and Wiebe, 2001), only recently with the application of molecular techniques has it become clear that seasonal changes in community composition are common in marine and freshwater ecosystems (Pinhassi and Hagstrom, 2000; Crump and Hobbie, 2005; Fuhrman et al., 2006; Shade et al., 2007). Temperature is often suggested to be one of the primary drivers of seasonal succession in bacterial communities and also a key factor in recently described biogeographic patterns in marine bacterial communities (Pommier et al., 2005).

To better understand how long-term (that is, climate change) and short-term changes in 
temperature (for example, mixing events, seasonality) affect bacterially mediated biogeochemical processes, it is important to mechanistically define how temperature and resources interact to change community composition and metabolism. To do this, we propose a mechanistic framework of bacterioplankton community dynamics that (a) allows for a variable biomass stoichiometry and (b) is composed of thermally adapted populations.

Traditionally, bacteria have been thought of as a low carbon/phosphorus (C:P) component of the pelagic food web with a constrained biomass stoichiometry (Fagerbakke et al., 1996). However, emerging evidence suggests that bacterial C:P ratios can be significantly higher than traditionally thought and highly variable (Elser et al., 1995; Villar-Argaiz et al., 2002; Hall, 2006). To reflect this, we used a Droop-style model to allow for a variable biomass stoichiometry and also to allow resource uptake to vary in relation to the changing cell quota of that resource. In addition, we allow for differences in minimal phosphorus quota $\left(Q_{\mathrm{P}}^{\mathrm{min}}\right)$ between cold-adapted and warm-adapted species by allowing the warm-adapted species to have a lower minimal phosphorus cell quota $\left(Q_{\mathrm{P}}^{\mathrm{min}}\right)$ than the cold-adapted species (Box 4), consistent with work from previous research including our own (Cole et al., 1993; Nishimura et al., 2005; Cotner et al., 2006). An advantage of including these biologically tenable biomass dynamics is that it also allows us to evaluate the role of bacteria as recyclers or sinks of limiting nutrients across thermal gradients.

The most essential aspect of the model presented here is the assumption of a trade-off between uptake $\left(v_{\max }\right)$ and respiration $\left(R_{\mathrm{B}}\right)$ in thermally adapted species. In our model, a species can either have the ability to uptake substrate at low temperature or have limited respiration at higher temperature, but not both. In prokaryotes, uptake and energy generation occur across a single membrane. Prokaryotic cells, therefore, must at all times maintain membrane fluidity in a range that optimizes the movement of transmembrane proteins and uptake, but does not allow protons to re-enter the cell via nonspecific channels, which would reduce protonmotive force and increase respiratory costs. Because the lipids that compose bacterial membranes have well-known thermal properties, the cell must be able to adjust membrane composition to changing temperature (Russell and Fukunaga, 1990). However, due to the energy and substrate requirements associated with alteration of extant lipids or de novo synthesis of novel lipids (Mansilla et al., 2004), alteration of membrane composition may not be feasible in nutrient-limited environments. Therefore, it is reasonable to assume that environmental pressures select for bacterial populations that contain membranes that are optimized for a specific temperature (Nichols et al., 1993). Bacterial communities sampled from two lakes in Central Minnesota, USA, in January and August were subjected to a range of temperatures. Respiration of the January community consistently increased more than respiration of the August communities with increasing temperatures (Hall and Cotner, 2007). This result is consistent with the proposed mechanism of thermal adaptation.

Below we evaluate how this trade-off in temperature-dependent physiological parameters results in changes in bacterial community composition due to competitive exclusion across thermal gradients. We use model simulations to show how changes in community composition can lead to more, or less, dynamic 'community' metabolic responses to temperature than experimental temperature forcing of a single population would predict. Finally, we solve the model analytically and show, by extending the graphical resource competition framework developed by Tilman (1980), how changing temperature results in different resource requirements and therefore changes in the competitive ability of thermally adapted species.

\section{Materials and methods}

We modified a two-resource, two species Droopstyle model (Thingstad, 1987) to include temperature dependence. The parameters and temperaturedependent functions in this model were estimated from empirical data derived from a series of experimental microcosms using bacterial communities from two lakes in North Central Minnesota, USA, during summer and winter (Hall, 2006; Hall and Cotner, 2007) and from a series of published studies, as noted. The full set of equations that define the model are listed in Boxes 1, 2 and 3, and the parameters used in each simulation are those listed in Box 4, unless otherwise specified. Below we describe how we arrived at the estimates for the values and functions used to incorporate temperature dependence into the model and for the values of the temperatureindependent parameters.

\section{Bacterial respiration $\left(\mathrm{R}_{B}\right)$}

To incorporate temperature dependence into bacterial respiration, $R_{\mathrm{B}}$ (Equation $(2 \mathrm{e})$ ), we assumed maintenance metabolism $\left(\rho_{\text {main }}\right.$-as defined in Equation (3c)) to be an increasing function of temperature. Depending on the value used for parameter $L$ in Equation (3c) (see Box 4), $\rho_{\text {main }}$ either saturates or increases, in an approximately exponential fashion, over the temperature range $2-34{ }^{\circ} \mathrm{C}$ (Figure 1a). Based on data from our experimental work, we modeled cold-adapted communities to have respiration increase more with temperature relative to warm-adapted communities (Hall and Cotner, 2007). Therefore, we selected the parameters in Equations (2e) and (3c) in a manner that allowed model output so that the 
Box 1 Differential equations that define the model

$$
\begin{aligned}
& \frac{\mathrm{d} P}{\mathrm{~d} t}=-v_{\mathrm{P}} B+D\left(P_{0}-P\right) \\
& \frac{\mathrm{d} C}{\mathrm{~d} t}=-v_{\mathrm{C}} B+D\left(C_{0}-C\right) \\
& \frac{\mathrm{d} B_{\mathrm{C}}}{\mathrm{d} t}=-v_{\mathrm{C}} B-B_{\mathrm{C}} D-R_{\mathrm{B}} B \\
& \frac{\mathrm{d} B_{\mathrm{P}}}{\mathrm{d} t}=-v_{\mathrm{P}} B-B_{\mathrm{P}} D \\
& \frac{\mathrm{d} B}{\mathrm{~d} t}=\left(\mu_{\mathrm{B}}-D\right) B
\end{aligned}
$$

Box 2 Parameter equations that define the model

$$
\begin{aligned}
& v_{\mathrm{P}}=\frac{\alpha_{\mathrm{P}} P}{K_{\mathrm{P}}+P} \\
& \alpha_{\mathrm{P}}=v_{\mathrm{P}}^{\max } \frac{Q_{\mathrm{P}}^{\max }-Q_{\mathrm{P}}}{Q_{\mathrm{P}}^{\max }-Q_{\mathrm{P}}^{\min }} \\
& v_{\mathrm{C}}=\frac{\alpha_{\mathrm{C}} C}{K_{\mathrm{C}}+C} \\
& \alpha_{\mathrm{C}}=v_{\mathrm{C}}^{\max } \frac{Q_{\mathrm{C}}^{\max }-Q_{\mathrm{C}}}{Q_{\mathrm{C}}^{\max }-Q_{\mathrm{C}}^{\min }} \\
& R_{\mathrm{B}}=\rho_{\mathrm{gro}} Q_{\mathrm{C}} \mu_{\mathrm{B}}+\rho_{\text {main }}\left(Q_{\mathrm{C}}-Q_{\mathrm{C}}^{\min }\right) \\
& \mu_{\mathrm{B}}=\mu_{\mathrm{B}}^{\max }\left(1-\frac{Q_{\mathrm{P}}^{\min }}{Q_{\mathrm{P}}}\right)\left(1-\frac{Q_{\mathrm{C}}^{\min }}{Q_{\mathrm{C}}}\right)
\end{aligned}
$$

cold-adapted species $(L=2)$ approximated empirical data of a bacterial community sampled in winter and the warm-adapted species $(L=8)$ approximated empirical data of a community sampled in summer (Figure 1b). By incorporating temperature dependence into the respiratory function $\left(R_{\mathrm{B}}\right)$ in this manner, we were able to allow for a consistent transition from a cold-adapted respiration response to a warm-adapted respiration response by adjusting the parameter $L$ in Equation (3c) while holding all other components of Equations (2e) and (3c) constant.

\section{Maximum uptake rate ( $\left.v^{\max }\right)$}

The range of values of maximal carbon and phosphorus uptake rates $\left(v_{\mathrm{C}}^{\max }\right.$ and $v_{\mathrm{P}}^{\max }$, respectively)
Box 3 Parameter equations that define the model

$v_{\mathrm{C}}^{\max }=\frac{1}{3.25+\left(m \mathrm{e}^{-0.175 T}\right)}$

$v_{\mathrm{P}}^{\max }=\frac{1}{11.25+\left(s \mathrm{e}^{-0.125 T}\right)}$

$\rho_{\text {main }}=\frac{1}{L+\left(7000 \mathrm{e}^{-0.25 T}\right)}$

Box 4 The parameter definitions and values used in each simulation, unless otherwise stated

$D=$ dilution rate, that is, mortality, $0.0075\left(\mathrm{~h}^{-1}\right)$

$P=$ nutrient pool concentration, initially $P_{0}=0.4\left(\mu \mathrm{mol} \mathrm{Pl} \mathrm{l}^{-1}\right)$

$C=$ carbon pool concentration, initially $C_{0}=40\left(\mu \mathrm{mol} \mathrm{Cl}^{-1}\right)$

$P_{0}=$ nutrient supply concentration, 0.175 (unless otherwise stated) $\left(\mu \mathrm{mol} \mathrm{l}{ }^{-1}\right)$

$C_{0}=$ carbon supply concentration, 40 (unless otherwise stated) $\left(\mu \mathrm{moll}^{-1}\right)$

$B=$ bacterial pool size $\left(\times 10^{9}{\left.\text { cells } \mathrm{l}^{-1}\right)}^{-1}\right.$

$B_{\mathrm{C}}=$ carbon content of bacterial biomass pool, initially 50 $\left(\mu \mathrm{mol} \mathrm{Cl}{ }^{-1}\right)$

$B_{\mathrm{P}}=$ phosphorus content of bacterial biomass pool, initially $0.5\left(\mu \mathrm{molP} l^{-1}\right)$

$B=$ bacterial pool size $\left(\times 10^{9}\right.$ cells $\left.^{-1}\right)$

$m=$ shape of $\mathrm{C}$ uptake function; from 5 (cold) to 27.5 (warm) (dimensionless)

$L=$ limit on respiration function; from 2 (cold) to 8 (warm) (dimensionless)

$s=$ shape of N uptake function; from 20 (cold) to 110 (warm)

(dimensionless)

$R_{\mathrm{B}}=$ specific respiration rate $\left(\mu \mathrm{mol} \mathrm{C}\right.$ per $\mathrm{h}$ per $10^{9}$ cells $)$

$\rho_{\text {gro }}=$ portion of respiration attributed to anabolism, 0.1

(dimensionless)

$\rho_{\text {main }}=$ portion of respiration attributed to catabolism $\left(\mathrm{h}^{-1}\right)$

$v_{\mathrm{P}}=$ rate of phosphorus uptake ( $\mu \mathrm{mol} \mathrm{P}$ per h per $\left.10^{9} \mathrm{cells}\right)$

$\nu_{\mathrm{P}}^{\max }=$ maximum rate of phosphorus uptake $(\mu \mathrm{mol} \mathrm{P}$ per $\mathrm{h}$ per

$10^{9}$ cells)

$v_{\mathrm{C}}=$ rate of carbon uptake ( $\mu \mathrm{mol} \mathrm{C}$ per h per $10^{9}$ cells)

$v_{\mathrm{C}}^{\max }=$ maximum rate of carbon uptake $\left(\mu \mathrm{molC}\right.$ per $\mathrm{h}$ per $10^{9}$ cells)

$\mu_{\mathrm{B}}=$ specific growth rate $\left(\mathrm{h}^{-1}\right)$

$\mu_{\mathrm{B}}^{\max }=$ maximum specific growth rate, $0.1\left(\mathrm{~h}^{-1}\right)$

$\alpha_{\mathrm{P}}=$ proportional phosphorus uptake constant $(\mu \mathrm{mol} \mathrm{P}$ per $\mathrm{h}$ per $10^{9}$ cells)

$\alpha_{\mathrm{C}}=$ proportional carbon uptake constant $\left(\mu \mathrm{mol} \mathrm{C}\right.$ per $\mathrm{h}$ per $10^{9}$ cells)

$Q_{\mathrm{C}}=$ cellular carbon content $\left(\mu \mathrm{mol}\right.$ C per $10^{9}$ cells)

$Q_{\mathrm{C}}^{\min }($ warm $)=Q_{\mathrm{C}}^{\min }($ cold $)=4.5 ; Q_{\mathrm{C}}^{\max }($ warm $)=Q_{\mathrm{C}}^{\max }($ cold $)=100$

$Q_{\mathrm{P}}=$ cellular phosphorus content $\left(\mu \mathrm{mol} \mathrm{P}\right.$ per $10^{9}$ cells)

$Q_{\mathrm{P}}^{\min }($ warm $)=0.02 ; Q_{\mathrm{P}}^{\min }($ cold $)=0.05$

$Q_{\mathrm{P}}^{\max }($ warm $)=Q_{\mathrm{P}}^{\max }($ cold $)=2.25$

$K_{\mathrm{P}}=$ half-saturation constant for P, $0.2\left(\mu \mathrm{mol} \mathrm{l}^{-1}\right)$

$K_{\mathrm{C}}=$ half-saturation constant for C, $0.3\left(\mu \mathrm{moll}^{-1}\right)$

were taken from published literature values of single populations and natural communities obtained during multiple seasons or over a range of experimentally manipulated temperatures (Kato, 1985; Robarts et al., 1991; Cotner and Wetzel, 1992; Button, 1998). Published results of the effect of temperature on $v^{\max }$ suggest either a positive-linear 

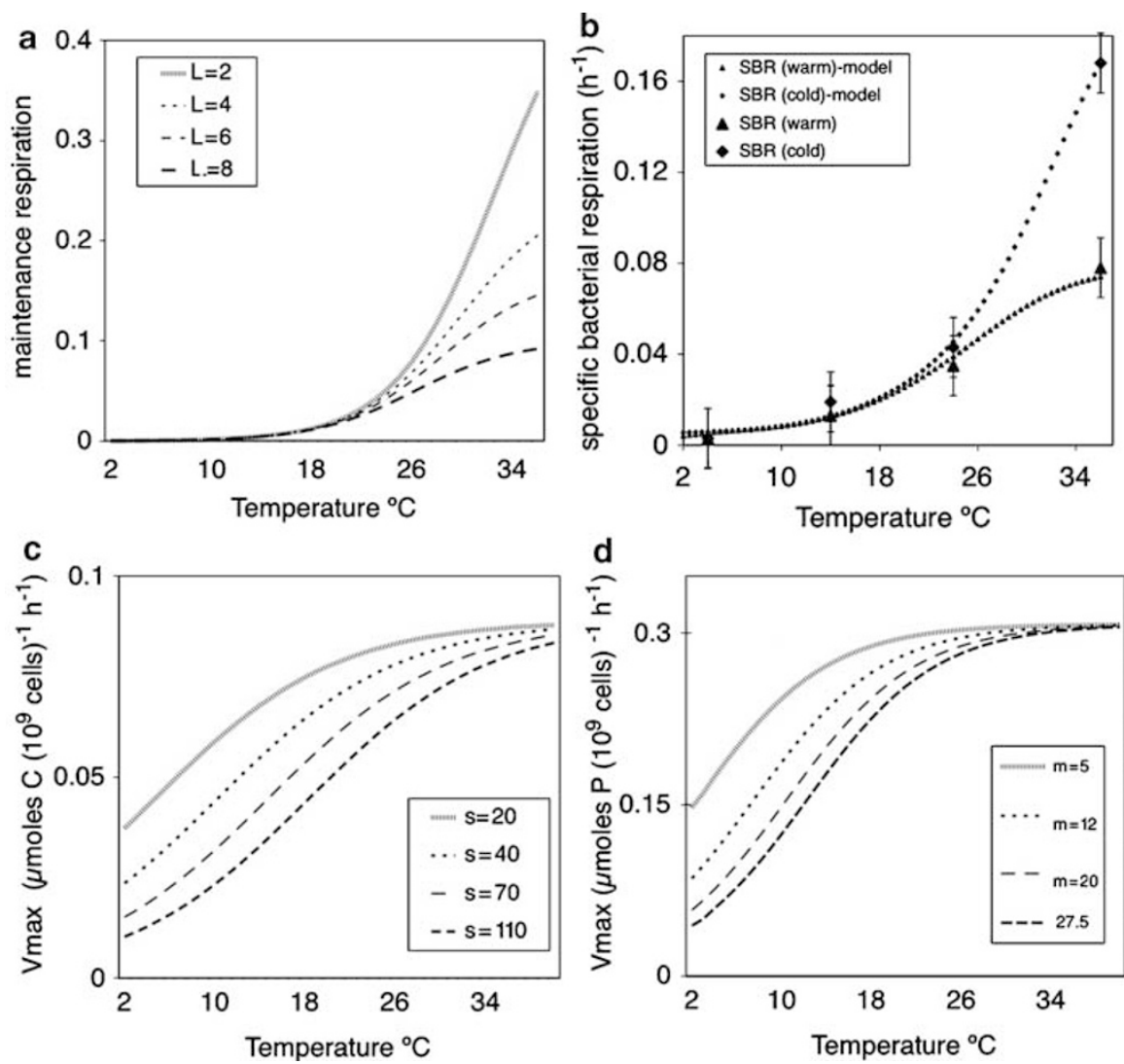

Figure 1 (a) The effect of temperature on the $\rho_{\text {main }}$ term for the values of $L$ used to parameterize the cold-adapted species $(L=2)$ and the warm-adapted species $(L=8)$ and two values in between. (b) The parameters in the respiration function were set so that the $R_{\mathrm{B}}$ of each species when simulated independently fits empirical data of a bacterial community isolated from a single lake in North Central Minnesota in August, SBR (warm) and in January, SBR (cold) (Hall and Cotner, 2007). (c) The effect of temperature on the carbon ( $v_{\mathrm{C}}^{\max }$ ) and $(\mathbf{d})$ phosphorus $\left(v_{\mathrm{P}}^{\max }\right)$ maximum uptake rates. The cold-adapted species is modeled with $s=20$ and $\mathrm{m}=5$ and the warm-adapted community has $s=110$ and $m=27.5$, for Equations (3a) and (3b), respectively.

or positive-saturating response to be a reasonable approximation of how $v^{\max }$ responds to increasing temperature (Kato, 1985). Therefore, we incorporated temperature dependence into each uptake function by maintaining a similar range of values for each 'species' and changing the shape of the response to temperature. For both carbon and phosphorus uptake, $v^{\max }$ of the warm-adapted species increases in an approximately linear fashion with temperature for most of the temperature range, while $v^{\max }$ of the cold-adapted species is a saturating function of temperature (Figures 1c and d, respectively). Using two different shapes to define the relationship between $v^{\max }$ and temperature allows cold-adapted communities to have higher maximum uptake rates at lower temperatures, but a dissipating advantage as temperature increases. The difference in the shape of the temperature- $v^{\max }$ relationship is manipulated by changing a single term in Equation (3a) or (3b). Similar to the respiration function (Equation (3c)), this allows us to evaluate a consistent transition from a cold-adapted uptake response to a warm-adapted uptake response by only adjusting the parameters $m$ and $s$ while holding all other parameters constant.

\section{Half-saturation constant (K)}

The values for the half-saturation constant $(K)$ were chosen to be 0.2 for phosphorus and 0.3 for carbon. Although we recognize that the half-saturation constant is most likely not independent of changes in temperature, previous researchers who attempted to find the relationship between $K$ and temperature were unable to illustrate a consistent trend (Tilman et al., 1981; Mechling and Kilham, 1983; Ellis-Evans and Wynn-Williams, 1985). However, because $v^{\max }$ in our model is an increasing function of temperature, holding $K$ constant results in a decreasing specific affinity $\left(v^{\max } / K\right)$ with a decreasing temperature, which is consistent with how bacterial physiology has been shown to respond to temperature (Nedwell, 1999).

\section{Cell quotas $\left(\mathrm{Q}_{P}\right.$ and $\left.\mathrm{Q}_{C}\right)$}

$Q_{\mathrm{P}}$ and $Q_{\mathrm{C}}$ were estimated by dividing the particulate carbon and particulate phosphorus in the $>1 \mu \mathrm{m}$ fraction by bacterial abundance from our microcosm experiments described elsewhere (Hall and Cotner, 2007) and reported here (Table 1). The 
Table 1 Empirically determined $Q_{\min }$ and $Q_{\max }$ values used to parameterize the model

$\begin{array}{llll}C & N & P & C: N: P\end{array}$

$Q_{\min }$ August $\quad 4.45(0.55) \quad 0.70(0.007) 0.035(0.007) \quad 127: 20: 1$

$Q_{\text {min }}$ January $\quad 3.36(1.53) \quad 0.28(0.035) \quad 0.030(0.014) \quad 112: 9: 1$

$Q_{\max }$ August $51.25(0.70) \quad 10.41(2.39) \quad 0.72(0.057) \quad 72: 15: 1$

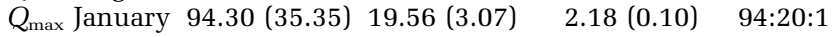

See text for details on calculations. Mean values are expressed as $\mu \mathrm{mol} \mathrm{C}, \mathrm{N}$ or P per $10^{9}$ cells ( \pm 1 s.d.).

minimum and maximum observed values were then used to estimate the range and quantity of the minimum cell phosphorous and minimum cell carbon content $\left(Q_{\mathrm{P}}^{\min }\right.$ and $\left.Q_{\mathrm{C}}^{\min }\right)$ and maximum cell phosphorus and maximum cell carbon content $\left(Q_{\mathrm{P}}^{\max }\right.$ and $Q_{\mathrm{C}}^{\max }$ ). Our estimates are consistent with values reported elsewhere and calculated using multiple methods (Fagerbakke et al., 1996; Villar-Argaiz et al., 2002).

Previous studies have suggested that warmadapted species have been selected to have lower phosphorus cell quota $\left(Q_{\mathrm{P}}^{\mathrm{min}}\right)$ than cold-adapted species (Nishimura et al., 2005). Also larger cells, indicative of higher nutrient content, have also been associated with cold hypolimnetic waters (Cole et al., 1993) and cells grown in culture were shown to have increasing $P$ requirements at lower temperatures when growth rate was held constant (Cotner et al., 2006). Therefore, we modeled cold-adapted species to have higher $Q_{\mathrm{P}}^{\min }$ than warm-adapted species.

\section{Additional parameters}

Resource supply rates $\left(P_{0}\right.$ and $\left.C_{0}\right)$ used in the simulations were chosen to produce dissolved chemistry values that mimicked the dissolved chemistry of natural lacustrine systems where phosphorus limits growth. Growth rate $\left(D=0.0075 \mathrm{~h}^{-1}\right)$ was chosen to represent slow-growing bacterioplankton common in oligotrophic systems (Rivkin et al., 1996). We modeled seasonal temperature using a sinusoidal function that approximated seasonal changes in eplilimnetic temperature from a small temperate lake (Wetzel, 2001). Other initial conditions were chosen to be similar to equilibrium conditions and had little to no impact on model output. Finally, it is important to note that growth rate at equilibrium, set as the dilution rate, could be met across the entire experimental temperature range, $2-34^{\circ} \mathrm{C}$, when species were run individually. Therefore, decreases in abundance when species are run together were due to competitive exclusion and not to washout. All simulations were performed using Berkeley Madonna version 8.3.12.
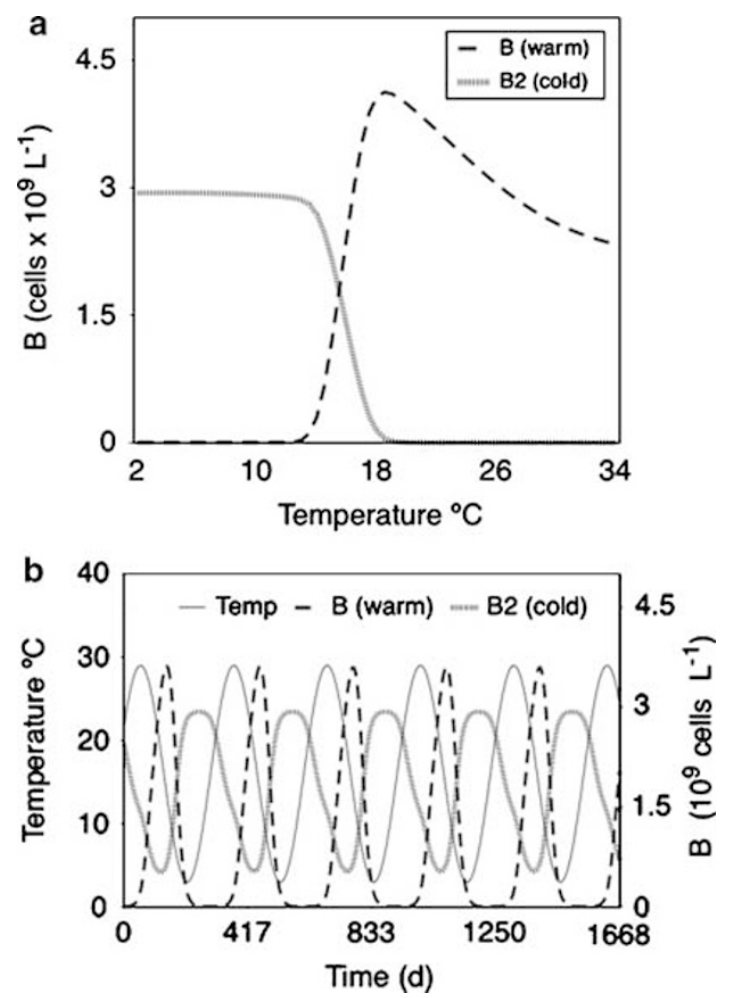

Figure 2 (a) The simulation model run of the changes in the abundance of each species at equilibrium from 2 to $34^{\circ} \mathrm{C}$. (b) The simulation model run of the changes in the abundance of each species at equilibrium from 2 to $34{ }^{\circ} \mathrm{C}$ when temperature is a sinusoidal function of time. The temperature function simulates the change of epilimnetic temperatures in a small temperate lake as described in the Materials and methods section. Seasonal oscillations between each population are shown. Note that species abundance is shown on the secondary $y$ axis while temperature is shown on the primary.

\section{Results}

\section{Simulations}

For the parameters in Box 4, we evaluated the bacterial abundance of each species at equilibrium for temperatures between 2 and $34^{\circ} \mathrm{C}$. As predicted, cold-adapted species dominated at cold temperatures $T<15^{\circ} \mathrm{C}$ and the warm-adapted species dominated at $T>15^{\circ} \mathrm{C}$ with a two species co-dominance point near $15^{\circ} \mathrm{C}$ (Figure 2a). When we applied a temperature function representative of seasonal changes in the epilimnion of temperate lakes, each species' population dynamics oscillated over time, with the cold-adapted species dominating in winter and spring, and the warm-adapted species dominating in summer and fall (Figure 2b). It is interesting to note that while the cold-adapted species clearly dominated during the colder seasons, the level of bacterial abundance never reached the levels of the warm-adapted species due to slower kinetics at lower temperatures.

We then evaluated how the change in community composition affected bacterial growth efficiency (BGE), biomass C:P and bacterial production (BP) 

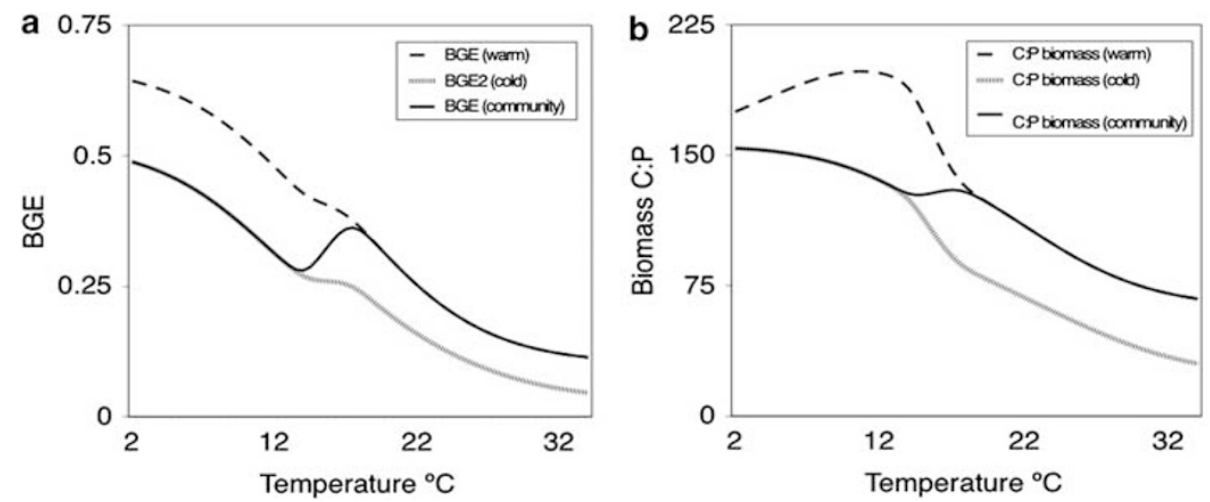

Figure 3 (a) The changes in bacterial growth efficiency (BGE) for each species and for the community as a whole at equilibrium across the range of temperatures $2-34^{\circ} \mathrm{C}$. Each species' contribution to community biomass was weighted relative to its biomass and combined to determine total community BGE. (b) The changes in biomass C:P for each species and for the community as a whole at equilibrium across the range of temperatures $2-34^{\circ} \mathrm{C}$. Each species' contribution to community biomass was weighted relative to its biomass and combined to determine total community biomass C:P.

of the community (that is, with each species normalized for relative abundance) for the same range of temperatures. For each species individually, BGE decreased with temperature over a range that is representative of previously reported values of BGE from natural communities (Figure 3a). However, due to the switch in the relative abundance between the cold-adapted and the warm-adapted species, community BGE decreased from 2 to $14^{\circ} \mathrm{C}$, increased from 14 to $19^{\circ} \mathrm{C}$ and again decreased from 19 to $34^{\circ} \mathrm{C}$ (Figure 3a).

Biomass C:P responded to temperature differently between species and across the temperature range. As temperature increased, the warm-adapted species C:P increased from 2 to $14{ }^{\circ} \mathrm{C}$ and then decreased from 14 to $34^{\circ} \mathrm{C}$, while the cold-adapted species decreased with increasing temperature (Figure 3b). Again, due to changes in species abundance across that range, the community signal was different from the signal from the individual populations. Community biomass C:P decreased from 2 to $14{ }^{\circ} \mathrm{C}$, did not change from 14 to $19^{\circ} \mathrm{C}$ and again decreased from 19 to $34{ }^{\circ} \mathrm{C}$ (Figure 3b).

Changes in BP mimic changes in biomass because growth rate $\left(\mathrm{h}^{-1}\right)=D$ at equilibrium, and $D$ was constant for all model runs. Nonetheless, it is interesting to note how changes in the biomass pool of each species result in changes in community BP across the range of simulated temperature. Community BP showed a unimodal response to temperature (Figure 4), which is qualitatively similar to observations from communities sampled in natural settings (Fuhrman and Azam, 1983; Simon et al., 1999). This pattern resulted from changes of each species with temperature and shifts in biomass across that temperature range. The cold-adapted species maintained a constant BP until $13{ }^{\circ} \mathrm{C}$ and then decreased while the warm-adapted species rapidly increased from 13 to $19^{\circ} \mathrm{C}$ and then gradually decreased from 19 to $34^{\circ} \mathrm{C}$ (Figure 4 ).

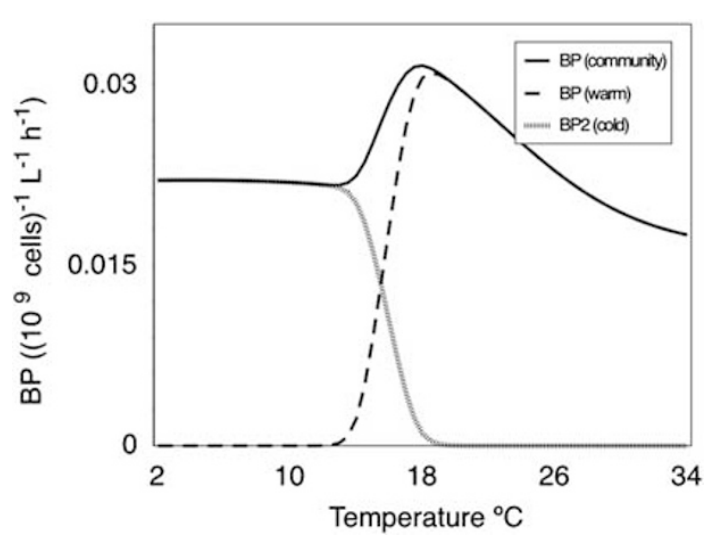

Figure 4 The relative contribution of each species to community bacterial production at equilibrium across the range of temperatures $2-34^{\circ} \mathrm{C}$.

\section{Theoretical analysis}

To explore the mechanisms behind the population dynamics outlined above, we analytically solved the model at equilibrium and looked at the changes in the zero net growth isoclines (ZNGIs) in tworesource space across the simulated temperature range. Below, we first define the ZNGIs with respect to cell quota $\left(Q_{\mathrm{P}}\right.$ and $Q_{\mathrm{C}}$ ) at equilibrium and then analytically show that cell quota at equilibrium is directly related to residual resource concentration (P and C). We then show graphically (Tilman, 1980) how competitive outcome changes with temperature. Finally, we discuss how different parameters affect the position of the ZNGIs and the implications for this in determining competitive outcome.

At equilibrium, growth, $\mu_{\mathrm{B}}$, is equal to the loss rate $D$, by definition:

$$
D=\mu_{\mathrm{B}}^{\max }\left(1-\frac{Q_{\mathrm{P}}^{\min }}{Q_{\mathrm{P}}}\right)\left(1-\frac{Q_{\mathrm{C}}^{\min }}{Q_{\mathrm{C}}}\right)
$$


Algebraically rearranging this equation allows us to solve for cellular carbon content $\left(Q_{\mathrm{C}}\right)$ at equilibrium:

$$
Q_{\mathrm{C}}=\frac{Q_{\mathrm{C}}^{\min }\left(1-\left(Q_{\mathrm{P}}^{\min } / Q_{\mathrm{P}}\right)\right)}{1-\left(Q_{\mathrm{P}}^{\min } / Q_{\mathrm{P}}\right)-\left(D / \mu_{\mathrm{B}}^{\max }\right)}
$$

Equation (1) (solved above for $Q_{\mathrm{C}}$ ) defines the ZNGIs in $Q_{\mathrm{P}}$ and $Q_{\mathrm{C}}$ space (Figure 5). Note that at equilibrium, the isocline does not depend on temperature (Equation (1)). Furthermore, it is important to note that the horizontal and vertical asymptotes (limits to the isocline) are given by

$$
\begin{gathered}
Q_{\mathrm{P}}=\frac{Q_{\mathrm{P}}^{\min }}{1-\left(D / \mu_{\mathrm{B}}^{\max }\right)} \\
Q_{\mathrm{C}}=\frac{Q_{\mathrm{C}}^{\min }}{1-\left(D / \mu_{\mathrm{B}}^{\max }\right)}
\end{gathered}
$$

Because Equations (2.1) and (2.2) set the limits for the ZNGIs, it is clear that when growth $(D$ at equilibrium) is much smaller than $\mu_{\mathrm{B}}^{\max }$, the position of the asymptote of the ZNGI approaches the minimum cell quota for either resource $\left(Q_{\mathrm{P}}^{\min }\right.$ or $\left.Q_{\mathrm{C}}^{\min }\right)$. Similarly, as $D$ approaches $\mu_{\mathrm{B}}^{\max }$, the position of the ZNGI moves away from the minimal cell quota. To translate ZNGIs from $Q_{\mathrm{P}}$ vs $Q_{\mathrm{C}}$ space to two-resource space (P and $\mathrm{C}$ ), we set $\mathrm{d} B_{\mathrm{P}} / \mathrm{d} t=0$ and combine the solution of $\mathrm{d} B_{\mathrm{P}} / \mathrm{d} t=0$ with the equation for $v_{\mathrm{P}}$ at equilibrium remembering that $Q_{\mathrm{P}}=B_{\mathrm{P}} / B$. This gives

$$
v_{\mathrm{P}}^{\max } \frac{Q_{\mathrm{P}}^{\max }-Q_{\mathrm{P}}}{Q_{\mathrm{P}}^{\max }-Q_{\mathrm{P}}^{\min }} \frac{P}{K_{\mathrm{P}}-P}=D Q_{\mathrm{P}}
$$

Rearranging Equation (3) to solve for $P$, we have

$$
P=\frac{D Q_{\mathrm{P}} K_{\mathrm{P}}}{v_{\mathrm{P}}^{\max }\left(\left(Q_{\mathrm{P}}^{\max }-Q_{\mathrm{P}}\right) /\left(Q_{\mathrm{P}}^{\max }-Q_{\mathrm{P}}^{\min }\right)\right)-D Q_{\mathrm{P}}}
$$

Similarly, setting $\mathrm{d} B_{\mathrm{C}} / \mathrm{d} t=0$, we have $v_{\mathrm{C}}-R_{\mathrm{B}}=D Q_{\mathrm{C}}$. Substituting in the complete equation for $v_{\mathrm{C}}$ and $R_{\mathrm{B}}$ from Box 2, we have

$$
\begin{aligned}
& v_{\mathrm{C}}^{\max } \frac{Q_{\mathrm{C}}^{\max }-Q_{\mathrm{C}}}{Q_{\mathrm{C}}^{\max }-Q_{\mathrm{C}}^{\min }} \frac{C}{K_{\mathrm{C}}+C} \\
& \quad-\left(\rho_{\text {gro }} Q_{\mathrm{C}} \mu_{\mathrm{B}}+\rho_{\text {main }}\left(Q_{\mathrm{C}}-Q_{\mathrm{C}}^{\min }\right)\right)=D Q_{\mathrm{C}}
\end{aligned}
$$

Rearranging Equation (4) and solving for $C$, we have $C=\frac{K_{\mathrm{C}}\left(D Q_{\mathrm{C}}+R_{\mathrm{B}}\right)}{v_{\mathrm{C}}^{\max }\left(\left(Q_{\mathrm{C}}^{\max }-Q_{\mathrm{C}}\right) /\left(Q_{\mathrm{C}}^{\max }-Q_{\mathrm{C}}^{\min }\right)\right)-\left(D Q_{\mathrm{C}}+R_{\mathrm{B}}\right)}$

Equations (3.1) and (4.1) define ZNGIs in P and C space. For a single temperature, all terms in Equations (3.1) and (4.1) with the exception of $Q_{\mathrm{P}}$ in Equation (3.1) and $Q_{C}$ in Equation (4.1) are constant. In other words, at a set temperature, $P$ is strictly a function of $Q_{\mathrm{P}}$ and $C$ is strictly a function of $Q_{\mathrm{C}}$. To translate ZNGIs from $Q_{\mathrm{P}}$ and $Q_{\mathrm{C}}$ space to $\mathrm{P}$ and $\mathrm{C}$ space and maintain a framework that is

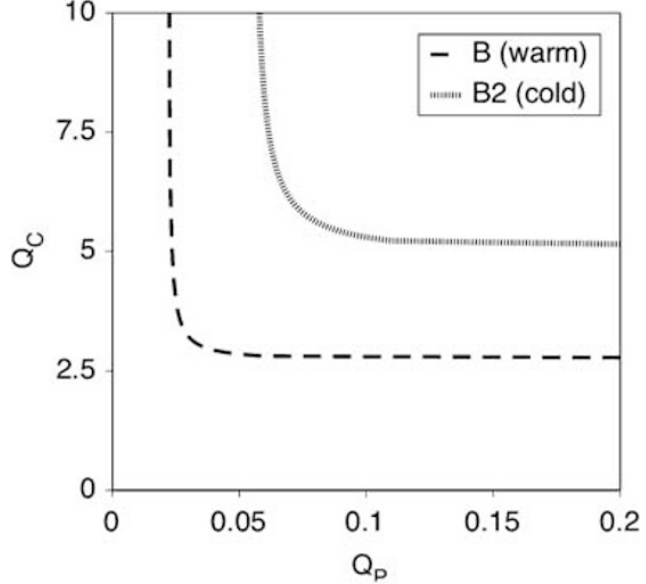

Figure 5 Zero net growth isoclines for the cold-adapted and warm-adapted species in cell quota $\left(Q_{\mathrm{P}}\right.$ and $\left.Q_{\mathrm{C}}\right)$ space using the parameters listed in Box 4, except $Q_{\mathrm{C}}^{\mathrm{min}}=2.5$ for the warmadapted species.

amenable to graphical analysis, it is essential that each point from the ZNGI in $Q_{P}$ and $Q_{C}$ space maps to one and only one point in $\mathrm{P}$ and $\mathrm{C}$ space. This is true for our model and can be demonstrated analytically by showing that the first derivatives of Equation (3.1) with respect to $Q_{\mathrm{P}}$, and Equation (4.1) with respect to $Q_{\mathrm{C}}$, remain positive for all values of $Q_{\mathrm{P}}$ and $Q_{\mathrm{C}}$. It is also important to note that while the ZNGIs we calculated in $Q_{\mathrm{P}}$ and $Q_{\mathrm{C}}$ space (Equations (2.1) and (2.2)) are temperature independent, the position of ZNGIs in $\mathrm{P}$ and $\mathrm{C}$ space is temperature dependent (because Equations (3.1) and (4.1) contain parameters that depend on temperature, that is, $v_{\max }$ and $\left.R_{\mathrm{B}}\right)$. At temperatures where the isoclines for each species cross, the area of coexistence and competitive exclusion is defined by calculating the resource consumption vectors for each species and plotting them from the two species equilibrium point. We arrive at the equation for the consumption vectors in the form used by Tilman (1980) but modified here to the form of our variable yield model:

$$
\begin{gathered}
D\left\lfloor\begin{array}{l}
P_{0}-P \\
C_{0}-C
\end{array}\right\rfloor-B_{1}\left\lfloor\begin{array}{l}
Q_{P 1} D \\
Q_{C 1} D+R_{B 1}
\end{array}\right\rfloor \\
-B_{2}\left\lfloor\begin{array}{l}
Q_{\mathrm{P} 2} D \\
Q_{\mathrm{C} 2} D+R_{\mathrm{B} 2}
\end{array}\right\rfloor=\left\lfloor\begin{array}{l}
0 \\
0
\end{array}\right\rfloor
\end{gathered}
$$

We derive this form of the resource consumption vector that resembles the more commonly seen version used by Tilman (1980), recalling that at equilibrium

$$
v_{\mathrm{P}} B=B_{\mathrm{P}} D=B Q_{\mathrm{P}} D
$$

and

$$
v_{\mathrm{C}} B=B_{\mathrm{C}} D+R_{\mathrm{B}} B=B\left(Q_{\mathrm{C}} D+R_{\mathrm{B}}\right)
$$

However, it is important to note that the consumption vectors for this Droop-style model as we have defined it are not constant in $\mathrm{P}$ and $\mathrm{C}$ space. 
Therefore, graphical analysis for resource consumption is not the same as in a constant yield resource model where consumption vectors can be graphically estimated and superimposed at the point of two species coexistence to define regions of coexistence and competitive outcome (Tilman, 1980). However, at the point of two species equilibrium, the consumption vectors can be calculated using Equation (5) and used to define regions of coexistence and competitive exclusion in the same manner as in resource competition theory (Turpin, 1988). Here, we do not evaluate the stability of two species equilibria because in many natural aquatic ecosystems, temperature is not static in time and therefore two species equilibrium points are unlikely. Below we show that competitive outcome changes with environmental temperature as the position of the ZNGIs changes with temperature. In a thermally stable environment, more attention could be paid to the possibility of coexistence and what level of thermal stability is necessary to maintain multi-species coexistence.

We used the ZNGIs defined in Equations (3.1) and (4.1) to evaluate competitive outcome graphically in $\mathrm{P}$ and $\mathrm{C}$ space following a traditional resource competition framework. We focused on how different temperatures affect the position of the ZNGIs for the cold- and warm-adapted species (as defined above) and how changes in these positions with changes in temperature affect competitive outcome.

Using the parameters for each species as defined in Box 4 for $T=7.5^{\circ} \mathrm{C}$, the cold-adapted species' ZNGI is below the ZNGI of the warm-adapted species and is therefore the superior competitor for all possible resource ratios (Figure 6). At $15^{\circ} \mathrm{C}$, the cold-adapted species has a lower minimum C requirement than the warm-adapted species, while the warm-adapted species maintains a lower requirement for $\mathrm{P}$ than the cold-adapted species; therefore, coexistence is possible and the competitive outcome depends on the nutrient supply ratio (Figure 6). For $T=27.5^{\circ} \mathrm{C}$, the warm-adapted species consistently has lower $\mathrm{P}$ and $\mathrm{C}$ requirements than the cold-adapted species and therefore can outcompete the cold-adapted species regardless of resource supply ratio (Figure 6). The competitive outcomes predicted by this graphical analysis are consistent with the simulation run for these parameter values, which shows a two species equilibrium near $15{ }^{\circ} \mathrm{C}$ and competitive dominance on either side of this temperature by one or the other species (Figure 2a).

As indicated by Equations (2.1) and (2.2), the position of the isoclines and therefore competitive outcome are sensitive to the minimal cell quota values set for the model. Increasing the value of $Q_{\mathrm{P}}^{\min }$ and $Q_{\mathrm{C}}^{\min }$ increases the level of resource necessary to maintain zero net growth (Figure 7). If the minimal cellular nutrient values for each community are changed for either carbon or the mineral nutrient, then the competitive outcome is altered and the temperature at which the two species equilibrium occurs is changed. For example, setting the values of $Q_{\mathrm{P}}^{\min }$ for the cold-adapted species equal to that of the warm-adapted species (for example, $Q_{\mathrm{P}}^{\mathrm{min}}=0.04$ ) shifts the temperature of the two species equilibrium to a higher temperature and therefore allows the cold-adapted species to maintain competitive dominance at warmer temperatures (Figure 8). In this scenario, for the parameter values used in Box 4, there is no temperature within the experimental range $\left(2-34{ }^{\circ} \mathrm{C}\right)$ where the warm-adapted species can outcompete the cold-adapted species at all resource ratios (Figure 8).

\section{Discussion}

The inability of observational studies from multiple environments to find consistent trends between temperature and bacterial metabolism might in part be due to the adaptation of local communities to a combination of the ambient temperature and the temporally integrated temperature regime at each locale. As we demonstrate above, changes in the relative abundance of populations within a community can give rise to community level metabolic responses that are not easily deduced from
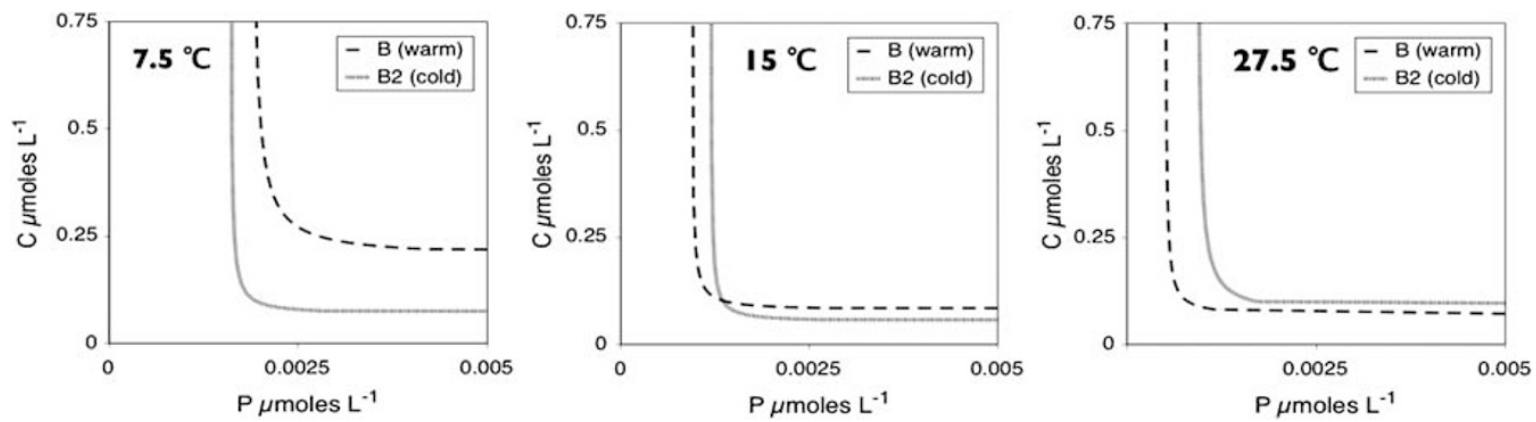

Figure 6 The three possible relative positions of the zero net growth isoclines (ZNGIs) in two-resource space for each species when all the parameters are set to the values in Box 4 . For $T=7.5^{\circ} \mathrm{C}$, the cold-adapted species' ZNGI is always outside the warm-adapted species and it is therefore competitively superior at all resource ratios. At $T=15^{\circ} \mathrm{C}$, the cold-adapted species is more limited by $\mathrm{P}$ while the warm-adapted species is more limited by $\mathrm{C}$, so coexistence is possible. At $T=27.5^{\circ} \mathrm{C}$, the warm-adapted species' ZNGI is entirely outside the cold-adapted species' isocline and therefore competitively superior at all resource ratios. 

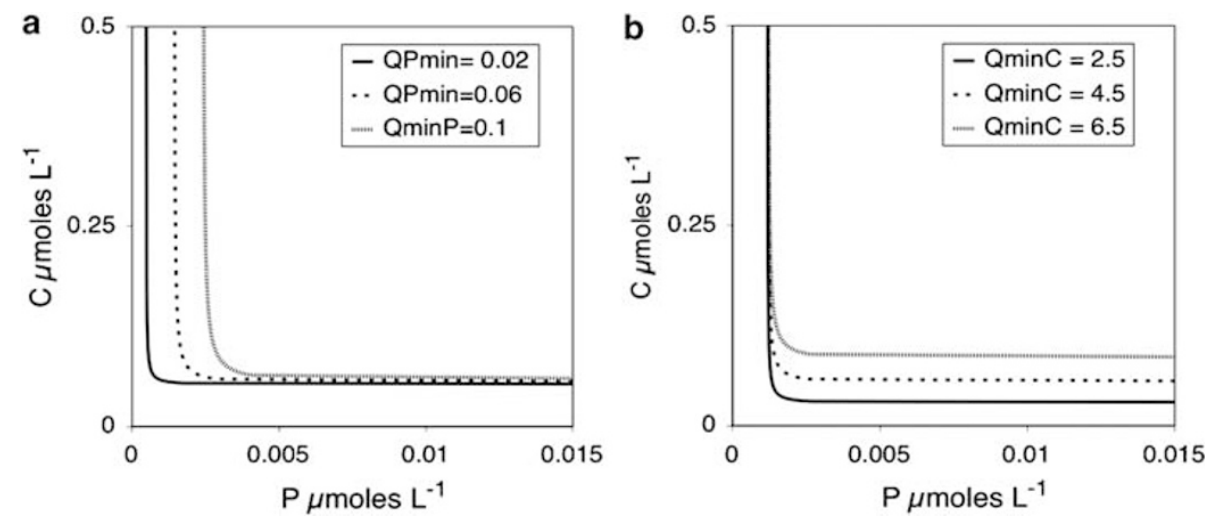

Figure 7 The effect of increasing $Q_{\mathrm{C}}^{\min }$ and $Q_{\mathrm{P}}^{\min }$ on the position of the zero net isocline of the cold-adapted species at $15^{\circ} \mathrm{C}$. The same effect is qualitatively true for each species across the range of temperatures $2-34^{\circ} \mathrm{C}$.
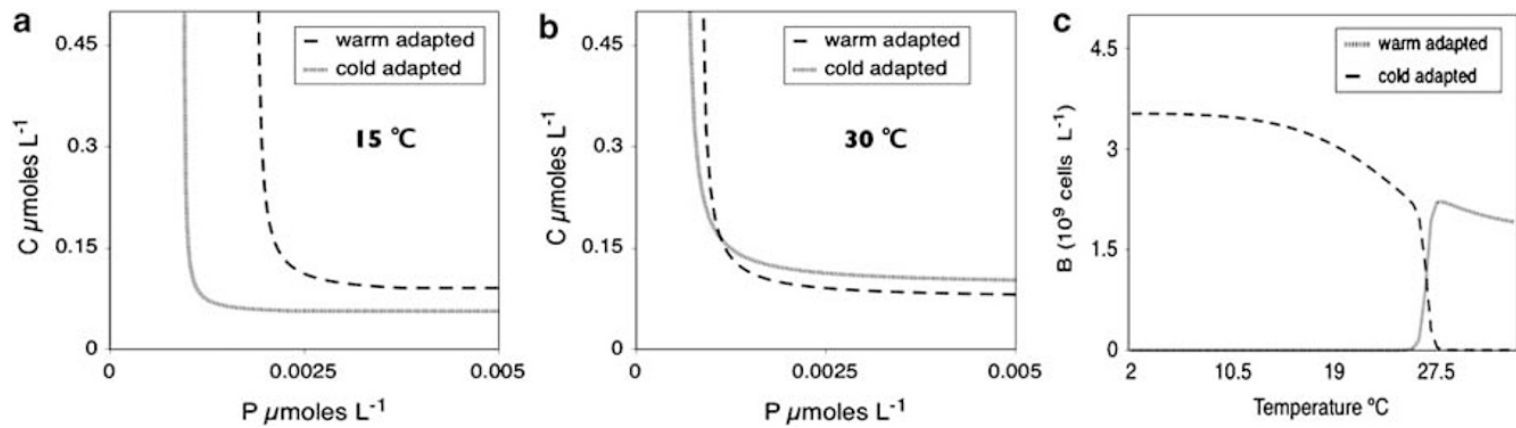

Figure 8 (a, b) The two possible relative positions of the zero net growth isoclines (ZNGIs) in two-resource space for each species when $Q_{\mathrm{P}}^{\min }($ cold $)=Q_{\mathrm{P}}^{\min }($ warm $)=0.04$ and all other parameters are set to the values in Box 4 . For $T=15^{\circ} \mathrm{C}$, the cold-adapted species' ZNGI is always outside the warm-adapted species. At $T=30^{\circ} \mathrm{C}$, the cold-adapted species is more limited by $\mathrm{C}$ while the warm-adapted species is more limited by $\mathrm{N}$, so coexistence is possible. When $Q_{\mathrm{P}}^{\min }(\operatorname{cold})=Q_{\mathrm{P}}^{\min }($ warm), there is always some resource ratio that allows the coldadapted species to outcompete the warm-adapted species at all temperatures within the experimental range. (c) Making the $Q_{\min }$ values equal increases the temperature at which the two species equilibrium occurs and allows the cold-adapted species to dominate over a larger range of temperatures.

understanding the temperature-physiology dynamics of a single population. For example, BGE has been reported to increase and decrease with respect to temperature (del Giorgio and Cole, 2000). Although BGE for each species we modeled decreased with increasing temperature, using our oversimplified community of two species we show how an increase $\left(10-14{ }^{\circ} \mathrm{C}\right)$, no change $\left(10-20^{\circ} \mathrm{C}\right)$ or a decrease $\left(2-10\right.$ and $15-34^{\circ} \mathrm{C}$ ) in BGE could be reported depending on the temperature interval over which BGE was measured (Figure 3a). A similar result can be shown for biomass C:P ratios in bacterioplankton (Figure 3b). Although in our model C:P either decreased or is held constant with respect to temperature, incorporating more species with similar C:P-temperature relationships would result in a positive relationship between community C:P and temperature when changes in the population abundance within the community are considered.

If temperature is indeed the main driver of community succession across seasonal and spatial thermal gradients, as has been proposed (Yannarell et al., 2003; Crump and Hobbie, 2005), then we must ask if bacterial communities adapted to high or low temperatures cycle elements differently from one another, and if so, how? If the manner in which we modeled our two species community is representative of natural communities, we would expect communities composed of cold-adapted species to have higher respiratory costs with increasing temperature relative to communities composed of warm-adapted populations. This suggests that increasing temperature in lacustrine systems could lead to increasing respiratory losses (that is, $\mathrm{CO}_{2}$ flux from the system) if the cold-adapted species maintain dominance but are exposed to higher temperature on average. Results from this model and our previous work (Hall, 2006) suggest that this is most likely to occur in systems with higher mineral nutrient content, as lower C:P resource ratios would allow for maintenance of cold-adapted organisms with higher minimal nutrient requirements. For example, at a resource supply ratio of 170, maintaining the amplitude of the seasonal temperature function but increasing the range of the temperature from $2-28{ }^{\circ} \mathrm{C}$ (Figure $2 b$ ) to $6-32{ }^{\circ} \mathrm{C}$ (Figure 9a) and finally $7-33^{\circ} \mathrm{C}$ (Figure 9b) allows the warm-adapted species to gradually displace the cold-adapted species in all seasons. However, decreasing the resource supply ratio at the highest 

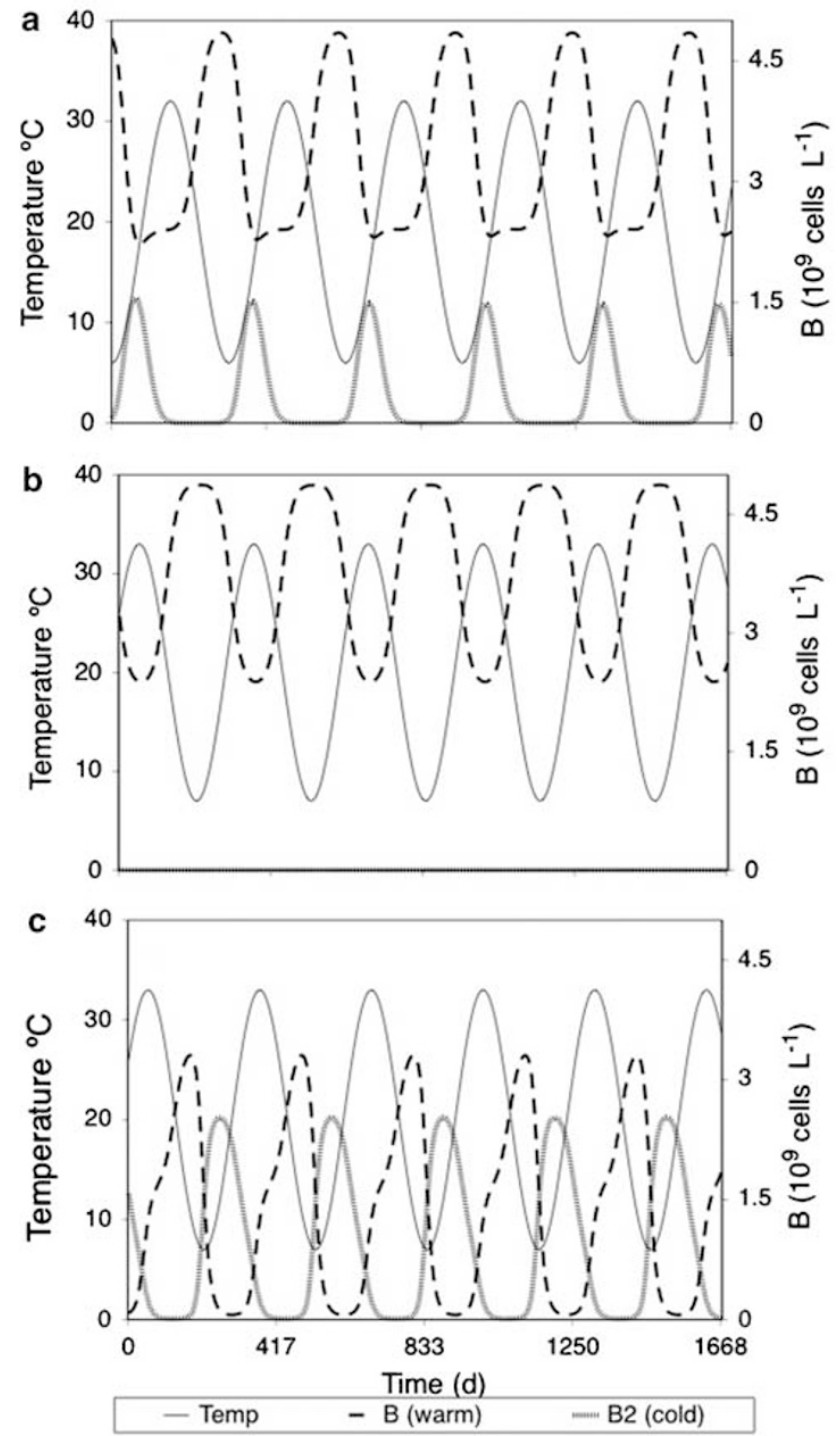

Figure 9 The warm-adapted species gradually displaces the cold-adapted species as the range of the seasonally oscillating temperatures increases from $2-28^{\circ} \mathrm{C}$ (Figure 4) to (a) $6-32{ }^{\circ} \mathrm{C}$ and finally (b) $7-33^{\circ} \mathrm{C}$ for a C:P supply ratio of 170 . When the C:P resource ratio is decreased to 115 (c) for the same range of temperature oscillations as in (b), the cold-adapted species is able to maintain seasonally oscillating abundance.

temperature range, $7-33^{\circ} \mathrm{C}$, to $\mathrm{C}: \mathrm{P}$ of 115 allows the cold-adapted species to maintain competitive dominance at the colder temperatures and oscillate seasonally (Figure 9c), with comparable dynamics to the lower temperature range for the more P-limited supply ratio (Figure $2 \mathrm{~b}$ ).

As mentioned above, previous studies have suggested that warm-adapted species have been selected to have lower phosphorus cell quota $\left(Q_{\mathrm{P}}^{\mathrm{min}}\right)$ than cold-adapted species (Nishimura et al., 2005). Also larger cells, indicative of higher nutrient content, have been associated with cold hypolimnetic waters (Cole et al., 1993). Here we modeled the cold-adapted species to have higher $Q_{\mathrm{P}}^{\min }$ than warm-adapted species (Box 4). If, on average, warm-adapted species do have lower mineral nutrient requirements than cold-adapted species, then warming could result in selection of organisms with a lower cellular nutrient requirement (that is, a higher C:P ratio), which would increase $\mathrm{P}$ mineralization by the bacterioplankton and increase the amount of carbon relative to $\mathrm{P}$ buried during sedimentation of particulate bacterial detritus (Cotner et al., 2006). Therefore, how increasing temperature will affect bacterial community composition and bacterially mediated biogeochemical processes is inextricably linked to the resource stoichiometry of a given aquatic system.

\section{Conclusion}

Identifying phenotypic properties of individual populations within natural bacterioplankton communities and understanding how changes in community composition drive changes in communitylevel metabolism is the next step to developing a mechanistic understanding of microbially mediated ecosystem processses. Although the genetic diversity in the natural bacterioplankton communities is vast (Venter et al., 2004), observational studies have shown that sometimes as few as five or six populations may dominate any one community at a given time (Pinhassi and Hagstrom, 2000). By identifying trade-offs and constraints on organismal physiology, it is possible to increase our understanding of bacterial community dynamics even when many populations remain unculturable or difficult to work with in laboratory settings.

By incorporating temperature dependence into two membrane-mediated physiological processes and assuming a single trade-off, we were able to mechanistically demonstrate how a changing thermal environment could result in shifts in bacterial community composition. Because each thermally adapted species has a different biogeochemical role, changes in community composition across thermal gradients affect how bacteria cycle elements and should be considered in larger scale models of ecosystem processes. Here we provide one approach to incorporating phenotypic changes in community composition within the bacterial 'black box' using thermally adapted populations. Increasing the resolution at which we address the effects of environmental forcing on bacterial metabolism will allow us better predictions of annual ecosystem level processes and improve projections of the effects of climate change on biogeochemical processes in aquatic ecosystems.

\section{Acknowledgements}

EKH would like to acknowledge Alma Hall for her support during the preparation of the manuscript. In addition, the quality of the manuscript was greatly improved by comments from three anonymous reviewers and discus- 
sions with the Litchman-Klausmeier lab group, including several specific comments from K Yoshiyama.

\section{References}

Azam F, Fenchel T, Field JG, Gray JS, Meyer-Reil LA, Thingstad TF. (1983). The ecological role of water-column microbes in the sea. Mar Ecol Prog Ser 10: 257-263.

Button DK. (1998). Nutrient uptake by microorganisms according to kinetic parameters from theory as related to cytoarchitecture. Microbiol Mol Biol Rev 62: 636-645.

Cho BC, Azam F. (1988). Major role of bacteria in biogeochemical fluxes in the ocean's interior. Nature 332: 441-443.

Cole JJ, Pace ML, Caracao NF, Steinhart GS. (1993). Bacterial biomass and cell size distributions in lakes: more and larger cells in anoxic waters. Limnol Oceanogr 38: 1627-1632.

Cotner JB, Makino W, Biddanda BA. (2006). Temperature affects stoichiometry and biochemical composition of Escherichia coli. Microb Ecol 52: 26-33.

Cotner JB, Wetzel RG. (1992). Uptake of dissolved inorganic and organic phosphorus compounds by phytoplankton and bacterioplankton. Limnol Oceanogr 37: 232-243.

Crump BC, Hobbie JE. (2005). Synchrony and seasonality in bacterioplankton communities of two temperate rivers. Limnol Oceanogr 50: 1718-1729.

del Giorgio PA, Cole JJ. (2000). Bacterial energetics and growth efficiency. In: Kirchman DL (ed). Microbial Ecology of the Oceans. Wiley-Liss: New York. p 542.

Ellis-Evans JC, Wynn-Williams DD. (1985). The interaction of soil and lake microflora at Signy Island. In: Siegfried WR, Condy PR, Laws RM (eds). Antarctic Nutrient Cycles. Springer Verlag: Berlin. pp 662-668.

Elser JJ, Chrzanowski TH, Sterner RW, Schampel JH, Foster DK. (1995). Elemental ratios and the uptake and release of nutrients by phytoplankton and bacteria in three lakes of the Canadian Shield. Microb Ecol 29: 145-162.

Fagerbakke KM, Heldal M, Norland S. (1996). Content of carbon, nitrogen, oxygen, sulfur and phosphorus in native aquatic and cultured bacteria. Aquatic Microb Ecol 10: 15-27.

Fuhrman JA, Azam F. (1983). Adaptations of bacteria to marine subsurface waters studied by temperature response. Mar Ecol Prog Ser 13: 95-98.

Fuhrman JA, Hewson I, Schwalbach MS, Steele JA, Brown MV, Naeem S. (2006). Annually reoccurring bacterial communities are predictable from ocean conditions. Proc Natl Acad Sci USA 103: 13104-13109.

Hall EK. (2006). Interacting effects of temperature and nutrients on the metabolism and biomass composition of natural bacterioplankton communities. $\mathrm{PhD}$ thesis, University of Minnesota.

Hall EK, Cotner JB. (2007). Interactive effect of temperature and resources on carbon cycling by freshwater bacterioplankton communities. Aquatic Microb Ecol 49: $35-45$.

Kato K. (1985). Seasonal observations of heterotrophic activity and active bacterial number in Lake Constance. Arch Hydrobiol Suppl 66: 309-319.

Mansilla MC, Cybulski LE, Albanesi D, Mendoza DD. (2004). Control of membrane lipid fluidity by molecular thermosensors. J Bacteriol 186: 6681-6688.

Mechling JA, Kilham SS. (1983). Temperature effects on silicon limited growth of the Lake Michigan diatom
Stephanodiscus minutus (Bacillariophyceae). J Phycol 18: $119-205$.

Nedwell DB. (1999). Effect of low temperature on microbial growth: lowered affinity for substrates limits growth at low temperature. FEMS Microbiol Ecol 30: 101-111.

Nichols DS, Nichols PD, McMeekin TA. (1993). Polyunsaturated fatty acids in Antarctic bacteria. Antarctic Sci 5: $149-160$.

Nishimura Y, Kim C, Nagata T. (2005). Vertical and seasonal variations of bacterioplankton subgroups with different nuclei acid contents: possible regulation by phosphorus. Appl Environ Microbiol 71: 5828-5836.

Pinhassi J, Hagstrom A. (2000). Seasonal succession in marine bacterioplankton. Aquatic Microb Ecol 21: 245-256.

Pomeroy LR, Wiebe WJ. (2001). Temperature and substrates as interactive limiting factors for marine heterotrophic bacteria. Aquatic Microb Ecol 23: 187-204.

Pommier T, Pinhassi J, Hagstrom A. (2005). Biogeographic analysis of ribosomal RNA clusters from marine bacterioplankton. Aquatic Microb Ecol 41: 79-89.

Rivkin RB, Anderson MR, Lajzerowicz C. (1996). Microbial processes in cold oceans. I. Relationship between temperature and bacterial growth rate. Aquatic Microb Ecol 10: 243-254.

Robarts RD, Sephton LM, Wicks RJ. (1991). Labile dissolved organic carbon and water temperature as regulators of heterotrophic bacterial activity and production in the lakes of Sub-Antarctic Marion Island. Polar Biol 11: 403-413.

Russell NJ, Fukunaga N. (1990). A comparison of thermal adaptation of membrane lipids in psychrophilic and thermophilic bacteria. FEMS Microbiol Rev 75: 171-182.

Shade A, Kent AD, Jones SE, Newton RJ, Triplett EW, McMahon KD. (2007). Interannual dynamics and phenology of bacterial communities in a eutrophic lake. Limnol Oceanogr 52: 487-494.

Simon M, Glockner FO, Amann R. (1999). Different community structure and temperature optima of heterotrophic picoplantkon in various regions of the Southern Ocean. Aquatic Microb Ecol 18: 275-284.

Thingstad TF. (1987). Utilization of N, P, and organic C by heterotrophic bacteria. I. Outline of a chemostat theory with a consistent concept of 'maintenance' metabolism. Mar Ecol Prog Ser 35: 99-109.

Tilman D. (1980). Resources: a graphical-mechanistic approach to competition and predation. Am Nat 116: 363-393.

Tilman D, Mattson M, Langer S. (1981). Competition and nutrient kinetics along a temperature gradient: an experimental test of a mechanistic approach to niche theory. Limnol Oceanogr 26: 1020-1033.

Venter JC et al. (2004). Environmental genome shotgun sequencing of the Sargasso Sea. Science 304: 66-74.

Villar-Argaiz M, Medina-Sanchez JM, Carrillo P. (2002). Microbial plankton response to contrasting climatic conditions: insights from community structure, productivity and fraction stoichiometry. Aquatic Microb Ecol 29: 253-266.

Wetzel RG. (2001). Limnology: Lake and River Ecosystems. Academic Press: San Diego, CA.

Yannarell AC, Kent AD, Lauster GH, Kratz TK, Triplett EW. (2003). Temporal patterns in bacterial communities in three temperate lakes of different trophic status. Microb Ecol 46: 391-405. 